\title{
Переваги малотравматичної аутодермопластики з використанням трансп.лантатів ультратонкого зрізу у хворих з опіками
}

\author{
A. O. KOVALCHUK, N. YU. OLIYNYK \\ SHEI "Ternopil State Medical University by I. Ya. Horbachevsky"
BENEFITS OF UNTRAUMATIC AUTODERMOPLASTY USING ULTRA THIN SLICE GRAFTS IN PATIENTS WITH BURNS

\begin{abstract}
У статті проведено дослідження ефективності пластичного закриття опікових ран тонкими та ультратонкими аутодермотрансплантатами. На прикладі 2 груп хворих доведено переваги малотравматичної аутодермопластики над класичним методом пластики ран. Доведено, що застосування розщеплених шкірних трансплантатів ультратонкого зрізу при проведенні аутодермопластики в обпечених хворих значно скорочує тривалість регенерації донорських ран, знижує об'єм післяопераційної крововтрати, покращує загальний стан пацієнтів та скорочує середній ліжко-день перебування пацієнтів у стаціонарі.

The article studied the efficiency of plastic closure of burn wounds by thin and ultra thin autodermotransplants. For example, 2 groups of patients proved the benefits of low-impact autodermoplasty classical method of plastic wounds. The application of split skin grafts of ultra thin slice during autodermoplasty in burned patients significantly reduces the regeneration of donor wounds, reduces the amount of postoperative blood loss, improves the general condition of patients and reduces the average bed day patient's stay in a hospital.
\end{abstract}

Постановка проблеми і аналіз останніх досліджень та публікацій. Щороку в Україні понад 50000 пацієнтів з опіковою хворобою звертаються за медичною допомогою до лікарів-спеціалістів. Слід зазначити, що велика кількість постраждалих, які отримали опікову травму в побуті, за медичною допомогою не звертаються, а займаються самолікуванням, що часто призводить до вторинного некрозу опікових ран та ускладнює перебіг опікової хвороби [1, 2].

Висока летальність, труднощі лікування, незадовільність функціональних і косметичних результатів вимагають пошуку нових шляхів та методів лікування обпечених. Основною причиною високої летальності обпечених $€$ гнійно-септичні ускладнення, які пов'язані з умовами розвитку запальної реакції в зоні термічного ураження, відторгненням і розплавленням некротичного струпа, зниженням рівня природної резистентності та імунологічної реактивності організму хворого [3].

Досить складною проблемою при лікуванні хворих з опіками є підбір препаратів та засобів медичного призначення, які б могли радикально змінювати розвиток запальної реакції та пришвидшувати регенерацію тканин, уражених термічним фактором [4-6].
Важливим завданням сучасної комбустіології $€$ вчасне відновлення втраченого шкірного покриву у хворих з глибокими опіками на значній поверхні тіла. Незважаючи на стрімкий розвиток і вдосконалення методів лікування, їх ефективність не досягає належного рівня.

Для досягнення бажаного результату пропонуємо використовувати метод малотравматичного пластичного закриття ран аутодермотрансплантатами ультратонкого зрізу в комбінації з гідрогелевими засобами III покоління та губчастими сорбуючими рановими покриттями.

Матеріали і методи. У Тернопільському обласному відділенні опікової травми та пластичної хірургії в період з 2012 до 2015 року під нашим спостереженням перебували 74 хворих з опіками різного ступеня тяжкості, віком від 18 до 82 років. Серед хворих чоловіків було 48 (64,0 \%), жінок - 26 (35,1 \%). Після виведення з шоку потерпілим на 3-5 добу проводили ранню хірургічну некректомію. Аутодермопластику виконували на 7-9 день. Пацієнтів поділили на 2 клінічних групи (табл. 1).

У всіх пацієнтів аутодермопластику виконували після появи зрілих грануляцій і крайової епітелізації 
Таблиця 1. Поділ хворих на клінічні групи

\begin{tabular}{|c|c|}
\hline Група 1 & Група 2 (контрольна) \\
\hline \multicolumn{2}{|c|}{ Кількість пацієнтів } \\
\hline $38(51,4 \%)$ & $36(48,6 \%)$ \\
\hline $\begin{array}{c}\text { Проведено аутодермопластику трансплантатами уль- } \\
\text { тратонкого зрізу 0,06-0,1мм }\end{array}$ & $\begin{array}{c}\text { Проведено аутодермопластику трансплантатами } \\
\text { товщиною 0,25 мм }\end{array}$ \\
\hline
\end{tabular}

рани та оцінки готовності грануляційної тканини до приживлення вільного шкірного трансплантата.

Техніка аутодермопластики не залежала від типу дефекту. Вільний шкірний аутотрансплантат (товщина 0,06-0,1 мм і 0,25 мм) отримували за допомогою автоматизованого дерматома з високопрецизійною ріжучою головкою одноразового використання. Аутологічні дермотрансплантати після перфорації (у співвідношенні 1:3) накладали на рани на відстані 0,5 см від краю рани і накривали гідрогелевою пов’язкою III покоління з сітчастою основою Sanospin NET в комбінації з губчастими сорбуючими рановими покриттями. Донорську рану закривали аналогічними регенеративними засобами в тій же самій послідовності. Першу перев’язку виконували на 3-й день після аутодермопластики.

У післяопераційному періоді ефективність аутодермопластики оцінювали за суб’єктивними відчуттями у пацієнтів обох спостережуваних груп. Основними скаргами були:

1. Біль у ділянці донорської та опікової поверхні.

2. Свербіж у ділянці донорської та опікової поверхні.

3. Відчуття стягнутості рани.

4. Печіння в ділянці донорської та опікової поверхні.

5. Загальна слабість, запамороченість.

6. Ломота в тілі.

7. Підвищені пітливість і спрага.

8. Швидка втомлюваність і поганий сон.

Традиційний вимір інтенсивності вираження скарги оцінювали за 10-бальною шкалою:

- 0 балів - повна відсутність негативних відчуттів;

- 3-4 бали - слабке вираження негативних відчуттів;

- 7-8 балів - середнє вираження негативних відчуттів;

- 9-10 балів - високе вираження негативних відчуттів.

Приживлення аутодермотрансплантатів розцінювалияк незадовільнеу випадку приживлення поверхні трансплантата до рани менш ніж 60 \%, задовільне приживлення - від 60 до 90 \% та майже повне приживлення - понад 90 \%.

Для об’єктивної оцінки стану опікової рани використовували абсолютні планіметричні величини (оцінка планіметричних показників за ме- тодом Попової). При проведенні планіметричних досліджень ранового дефекту, крім загальної площі рани, також враховували такі показники, як: площа некрозу, площа грануляційної тканини та площа епітелізації стосовно загальної площі опіку [7].

Під час операції, після забору аутодермотрансплантатів, вимірювали об’єм крововтрати з ранової поверхні донорської ділянки. Крововтрату вимірювали гравіметричним методом - це ваговий спосіб визначення величини крововтрати шляхом зважування адсорбуючого матеріалу (серветок, операційної білизни) до і після операції. При цьому різниця в 1 г дорівнює 1 мл крові $[8,9]$.

Після закриття ран сітчастими гідрогелевими засобами та губчастими адсорбентами останні знімали з ранової поверхні через 5 хв, закриваючи рану новим аналогічним губчастим адсорбентом, при цьому гідрогелеве покриття залишалось на рані і було добре фіксоване. Просякнуте геморагічним рановим ексудатом губчасте ранове покриття зважували на електронній вазі (ORON-OS OK51G), попередньо відкаліброваній на нульову поділку.

Для достовірного визначення об’єму крововтрати з донорської ранової поверхні порівнювали рівень гемоглобіну i гематокриту до i після проведення аутодермопластики.

Гематокритний показник (гематокрит) характеризує відсотковий об’єм формених елементів (а саме еритроцитів) у крові. Для визначення гематокриту використовували гематокритний капіляр або мікропіпетку, центрифугу на 8000 об/хв, пластилін, водний розчин гепарину (з активністю 5000 ОД/мл), 96 \% спирт, 2 \% розчин йоду спиртовий, вату, гумову грушу, градуйовану на 100 поділок. Гематокритну піпетку після промивання розчином гепарину продували гумовою грушею. Висушували піпетку і заповнювали кров'ю на 7/8 довжини. Отвір піпетки заклеювали пластиліном і центрифугували протягом 5 хв при 8000 об/хв. Після центрифугування визначали відсоток формених елементів стосовно загального об’єму крові, тобто гематокритну величину [10-12].

Для визначення об’єму крововтрати використовували гематокритний метод Moore [13]. Суть методу полягала в ефекті розведення циркулюючої крові плазмою. Про ступінь розведення судили за зниженям гематокритного числа.

Розрахунок проводили за формулою:

$\mathrm{KB}=\mathrm{O}$ Қв $\cdot(\mathrm{HtB}-\mathrm{Ht} \phi) / \mathrm{Ht}$,

де КВ - об’єм крововтрати; 
ОЦКв - для чоловіків 76 мл/кг, для жінок - 71 мл/кг;

Htв - вихідний рівень гематокриту (середній показник для чоловіків - 43 \%, для жінок - 41 \%;

Нtф - гематокрит фактичний, визначений після проведення аутодермопластики.

Крім того, використовували колориметричний метод визначення об’єму післяопераційної крововтрати, запропонований А. Ф. Криницким. При цьому під час операції біля операційного столу ставили ємність з водою об' ємом 10 л. У цю ємність в ході операції кидали всі просякнуті кров'ю матеріали (серветки, тампони, сорбуючі матеріали). Однорідність розчину досягали помішуванням [14].

Для визначення рівня гемоглобіну в отриманому розчині використовували колориметричний метод Салі. Принцип методуполягає втакому:при додаванні до крові соляної кислоти гемоглобін перетворюється на хлористоводневий гематин коричневого кольору, інтенсивність якого прямо пропорційна вмісту гемоглобіну. Отриманий розчин хлористоводневого гематину розводять водою до кольору стандарту. Цей метод визначення кількості гемоглобіну дає результати з точністю до 10 \%. Для визначення використовують гемометр Салі. Це штатив 3 трьома пробірками. У крайніх запаяних пробірках міститься $1 \%$ розчин хлористоводневокислого гематину. Середня пробірка має поділки від 0 до $23 \times 10$ г/л і призначена для визначення гемоглобіну в досліджуваній крові [15].

Визначивши гемоглобін розчину і знаючи гемоглобін крові пацієнта, визначений до проведення операції, отримуємо об’ єм крововтрати, підставивши отримані величини у формулу:

$\mathrm{KB}=(\mathrm{Hbp} \cdot \mathrm{V}) /(\mathrm{HbB} \cdot 25)$,

де КВ - об'єм крововтрати в мл;

Hbp - гемоглобін гемолізованої крові в рідині 3 ємності;

Нbв - гемоглобін крові пацієнта, визначений до операції;

V - об’єм води в ємності в мл;

25 - постійний коефіцієнт для гемометра Салі.
Результати досліджень та їх обговорення. У ході спостереження було вивчено 74 карти пацієнтів, які перебували на лікуванні в Тернопільському обласному відділенні опікової травми та пластичної хірургії і яким виконували аутодермопластику ранових дефектів внаслідок опіків.

Найбільш часто ураження розміщувались на верхніх кінцівках (55 хворих з 74 - близько 55 \%), на нижніх кінцівках (16 пацієнтів, або 22 \%), на тулубі (3 пацієнти, або 4 \%).

Розподіл пацієнтів залежно від розміщення дефекту шкіри показано в таблиці 2.

Після проведених дерматопластичних операцій у пацієнтів контрольної групи 3 використанням тонких аутодермотрансплантатів товщиною 0,250,3 мм повне приживлення спостерігали в 10336 пацієнтів (27,8 \%), задовільне - у 19 хворих (52,7 \%), незадовільне - у 7 пацієнтів (19,4 \%).

Зовсім іншу динаміку приживлення аутодермотрансплантатів спостерігали у хворих 1-ї групи, рани яких закривали аутодермотрансплантатами ультратонкого зрізу (табл. 3). При цьому повне приживлення дермотрансплантатів спостерігали в 17 з 38 пацієнтів (44,7 \%), задовільне - у 16 хворих (42,1%), незадовільне - у 5 пацієнтів (13 \%) (табл. 3).

Слід зазначити, що епітелізація донорських ран у пацієнтів 1-ї групи відбувалась значно швидше порівняно з контрольноюгрупою. Так, у хворих 1-ї групи відмічено повну епітелізацію донорських ран на 7-8 добу, тоді як у пацієнтів контрольної групи донорські рани епітелізувались на 10-11 добу (табл. 4).

Кожного дня до повного загоєння ран проводили суб’єктивне обстеження, метою якого було виявити основні типи скарг пацієнтів після проведення аутодермопластики.

Хворі в перші години після аутодермопластики скаржились на біль у проекції опікових та донорських ран, спрагу, були в повній свідомості, неспокійні. Турбували нудота, ослаблення, лихоманка. В крові відмічали помірний лейкоцитоз, що знижувався, особливо на наступний день після проведення ау-

Таблиця 2. Розміщення дефекту шкіри на тілі пацієнтів спостережуваних груп

\begin{tabular}{||l|c|c||}
\hline \multicolumn{1}{|c|}{ Розміщення дефекту шкіри на тілі пацієнта } & Група 1 & Група 2 (контрольна) \\
\hline На верхніх кінцівках & 26 & 25 \\
\hline На нижніх кінцівках & 8 & 8 \\
\hline На тулубі & 2 & 1 \\
\hline
\end{tabular}

Таблиця 3. Динаміка приживлення аутодермотрансплантатів у пацієнтів спостережуваних груп

\begin{tabular}{||l|c|c|c|c||}
\hline \multicolumn{1}{|c|}{ Приживлення } & \multicolumn{2}{|c||}{ Група 1 } & \multicolumn{2}{|c|}{ Група 2 (контрольна) } \\
\hline Всього пацієнтів & 38 & $100 \%$ & 36 & $100 \%$ \\
\hline Повне приживлення & 17 & $44,7 \%$ & 10 & $27,8 \%$ \\
\hline Задовільне приживлення (60-90 \% площі рани) & 16 & $42,1 \%$ & 19 & $52,7 \%$ \\
\hline Незадовільне приживлення (менш ніж 60\% площі рани) & 5 & $13 \%$ & 7 & $19,4 \%$ \\
\hline \hline
\end{tabular}


Таблиця 4. Динаміка швидкості епітелізації донорських ран у пацієнтів спостережуваних груп

\begin{tabular}{|c|c|c|}
\hline \multirow{2}{*}{ Дні } & Група 1 (дослідна) & Група 2 (контрольна) \\
\hline & \multicolumn{2}{|c|}{ площа епітелізації } \\
\hline 1-Й & - & - \\
\hline 2-й & $7,2 \%$ & $6,9 \%$ \\
\hline 3-й & $13,1 \%$ & $13,7 \%$ \\
\hline 4-й & $27,9 \%$ & $20,3 \%$ \\
\hline 5-Й & $39,7 \%$ & $25,3 \%$ \\
\hline 6-й & $56,3 \%$ & $36,3 \%$ \\
\hline 7-й & $77,9 \%$ & $49,9 \%$ \\
\hline 8-й & $96,5 \%$ & $60,6 \%$ \\
\hline 9-й & & $75,1 \%$ \\
\hline 10-й & & $88,3 \%$ \\
\hline 11-й & & $94,2 \%$ \\
\hline
\end{tabular}

тодермопластики $((9,1 \pm 1,2) \times 10 \%$ л $)$ у групі 1 та $((11,4 \pm 1,5) \times 10 \%$ ) у групі 2 .

На 2-3-й день після операції загальний стан хворих покращувався, температура тіла знижувалась, лихоманка зникала. Температура тіла в середньому становила 37,2-38,0 ㄷ у пацієнтів обох груп. Дані загального аналізу крові вказували на наявність зменшення запалення в організмі: лейкоцитоз досягав рівня $(7,5 \pm 1,3) \times 10 \%$ л у групі 1 та $(9,2 \pm 1,6) \times 10 \%$ в групі 2 зі зсувом лейкоцитарної формули вліво.

На 6-7 день після аутодермопластики помітно значне покращення загального стану хворих як групи 1, так і групи 2. Були скарги на незначний біль у ділянках опікової та донорської ран, відчуття стягненості в проекції донорської рани. Скарги на загальну слабість і втомлюваність були лише у 35 осіб, а на підвищену пітливість і спрагу - у 22 пацієнтів обох груп спостережень. Водночас слід зазначити, що значно менше скарг було виявлено у пацієнтів 1-ї групи порівняно з 2-ю групою (табл. 5).

При проведенні аутодермопластики спостерігали тенденцію до вираженої крововтрати залежно від товщини аутодермотрансплантата.

Під час проведення операції у кожного пацієнта групи 2 (товщина шкірного трансплантата 0,25 мм) площа отриманих аутодермотрансплантантів у середньому становила 585,4 см², при цьому середній об’єм крововтрати становив 223,4 мл, тобто кровотеча об’ємом 3,8 мл з ранової поверхні площею 10 см². Площа закриття глибоких ран перфорованими дер- мотрансплантатами в середньому складала 6,5 \% поверхні тіла.

При лікуванні пацієнтів групи 1 (товщина шкірного трансплантата 0,06-0,01 Мм) процес забору аутодермотрансплантатів супроводжувався значно меншою крововтратою, порівняно з групою 2. Це давало можливість здійснювати забір дермотрансплантатів значно більшої площі, яка в середньому становила 992,6 см², при середній крововтраті 234,4 мл або об’ємом 2,25 мл з ранової поверхні площею 10 см². Таким чином, у кожного хворого площа одномоментного закриття ран перфорованими аутодермотрансплантатами становила $10,8 \%$.

Як згадувалось вище, після отримання дермотрансплантата на донорську ділянку, яка кровоточить, накладали сітчасте ранове покриття Sanospin FOAM, поверх якого накладали губчасте сорбуюче покриття.

Для закриття ранової поверхні пацієнтів групи 1 площею 992,6 см² використовували в середньому 10 губчастих адсорбентів площею 100 см$^{2}$. Для лікування пацієнтів 2-ї групи з рановою поверхнею площею5 585,4 см² використали в середньому 6 губчастих сорбентів.

Отримані дані про об’єм втраченої пацієнтом крові відображені у таблиці 6.

Аналогічні тенденції виявлено при вимірюванні рівня гемоглобіну та гематокриту до і після операційного втручання у пацієнтів обох груп (табл. 7, 8), що підтверджувало малотравматичність методики ультратонкого зрізу аутодермотрансплантатів.

Таблиця 5. Оцінка ефективності аутодермопластики за суб'єктивними відчуттями у пацієнтів обох спостережуваних груп

\begin{tabular}{|c|c|c|}
\hline Основні скарги & Група 1 & 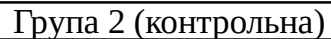 \\
\hline Біль & З бали & 5 балів \\
\hline Свербіж & 2 бали & 6 балів \\
\hline Відчуття стягнутості рани & 4 бали & 6 балів \\
\hline Печіння & 2 бали & 4 бали \\
\hline Загальна слабість, запаморочення & 3 бали & 5 балів \\
\hline Ломота в тілі & 1 бал & 5 балів \\
\hline Підвищені пітливість і спрага & 3 бали & 6 балів \\
\hline Швидка втомлюваність і поганий сон & 4 бали & 7 балів \\
\hline
\end{tabular}


Таблиця 6. Об'єм післяопераційної крововтрати з ділянок донорських ран у пацієнтів обох груп спостереження

\begin{tabular}{|c|c|c|}
\hline & Група 1 & Група 2 \\
\hline Площа ранової поверхні & $992,6 \mathrm{cM}^{2}$ & $585,4 \mathrm{CM}^{2}$ \\
\hline Кількість губчастих сорбентів площею 100 см² & 10 шт & 6 шт \\
\hline Маса губчастого сорбенту разом із втраченою кров’ю & 234,4 г & 223,4 г \\
\hline Маса 1 губчастого сорбенту разом з втраченою кров’ю & $23,44 \Gamma$ & $37,23 \Gamma$ \\
\hline
\end{tabular}

Згідно з даними колориметричного методу визначення рівня гемоглобіну також було виявлено значно нижчий рівень післяопераційної крововтрати у па-

цієнтів 1-ї групи, що в черговий раз підтвердило високу ефективність запропонованого методу аутодермопластики ран ультратонкими трансплантатами (табл. 9).

Таблиця 7. Рівень гематокриту в пацієнтів 1-ї групи в передопераційному та післяопераційному періодах

\begin{tabular}{||c|c|c|c|c||}
\hline \multirow{3}{*}{ Стать } & \multicolumn{4}{|c||}{ Група 1 } \\
\cline { 2 - 5 } & $\begin{array}{c}\text { рівень гематокриту до } \\
\text { проведення аутодермопластики }\end{array}$ & $\begin{array}{c}\text { рівень гематокриту після } \\
\text { проведення аутодермопластики }\end{array}$ & $\begin{array}{c}\text { різниця } \\
\text { показників }\end{array}$ & $\begin{array}{c}\text { середній об’єм } \\
\text { крововтрати }\end{array}$ \\
\hline Чоловіки & $43 \%$ & $41,1 \%$ & 1,83 & 260 мл \\
\hline Жінки & $41 \%$ & $38,9 \%$ & 2,1 & 250 мл \\
\hline \hline
\end{tabular}

Таблиця 8. Рівень гематокриту в пацієнтів 2-ї групи в передопераційному та післяопераційному періодах

\begin{tabular}{||c|c|c|c|c||}
\hline \multirow{3}{*}{ Стать } & \multicolumn{3}{|c||}{ Група 2 } \\
\cline { 2 - 5 } & $\begin{array}{c}\text { рівень гематокриту до } \\
\text { проведення аутодермопластики }\end{array}$ & $\begin{array}{c}\text { рівень гематокриту після } \\
\text { проведення аутодермопластики }\end{array}$ & $\begin{array}{c}\text { різниця } \\
\text { показників }\end{array}$ & $\begin{array}{c}\text { середній об’єм } \\
\text { крововтрати }\end{array}$ \\
\hline Чоловіки & $45 \%$ & $42,1 \%$ & 2,9 & 390 мл \\
\hline Жінки & $42 \%$ & $38,8 \%$ & 3,2 & 380 мл \\
\hline \hline
\end{tabular}

Таблиця 9. Об'єм післяопераційної крововтрати з ділянок донорських ран у пацієнтів обох груп спостереження

\begin{tabular}{|c|c|c|c|c|c|}
\hline \multicolumn{3}{|c|}{ Група 1} & \multicolumn{3}{|c|}{ Група 2} \\
\hline рівень гемоглобіну & рівень гемоглобіну & об’єм & рівень гемоглобіну & рівень гемоглобіну & об’єм \\
\hline $\begin{array}{l}\text { до проведення ау- } \\
\text { тодермопластики }\end{array}$ & $\begin{array}{c}\text { гемолізованої крові } \\
\text { в рідині }\end{array}$ & $\begin{array}{c}\text { крововтрати } \\
\text { (мл) }\end{array}$ & $\begin{array}{c}\text { до проведення ауто- } \\
\text { дермопластики }\end{array}$ & $\begin{array}{c}\text { гемолізованої крові } \\
\text { в рідині }\end{array}$ & $\begin{array}{c}\text { крововтрати } \\
\text { (мл) }\end{array}$ \\
\hline \multicolumn{6}{|c|}{ Середній рівень гемоглобіну в чоловіків } \\
\hline 145 & 92,4 & 255 & 147 & 135,9 & 370 \\
\hline \multicolumn{6}{|c|}{ Середній рівень гемоглобіну в жінок } \\
\hline 125 & 78,1 & 250 & 130 & 126,7 & 390 \\
\hline
\end{tabular}

Висновки. 1. Як бачимо з вищенаведених даних лабораторних показників та клінічних спостережень, проведення аутодермопластики з використанням дермотрансплантатів ультратонкого зрізу $\epsilon$ ефективною методикою для відновлення втраченого шкірного покриву та загоєння ранового дефекту у хворих з глибокими опіками. Вагомим доказом цього є приживлення ультратонкого трансплантата у 77 \% пацієнтів у значно коротші терміни порівняно 3 технікою з використанням трансплантатів товщиною 0,25 мм, що скорочує час перебування пацієнтів у стаціонарі. Застосування аутодермопластики ультратонкого зрізу дозволяє зменшити площу донорських ран майже у 2 рази. Так, при застосуванні трансплантатів товщиною 0,06 одномоментно можна закрити 992,6 см² ранового дефекту при середній крововтраті 234,4 мл. Для порівняння, при використанні трансплантатів товщиною 0,25 мм площа отриманих аутодермотрансплантатів у середньо- му становила лише 585,4 см², при цьому середній об’єм крововтрати становив 223,4 мл. Водночас об’єм крововтрати з донорських ділянок збільшився лише на 11 мл - при майже в 2 рази білышій площі забору ультратонких трансплантатів. Також важливим $€$ значне покращення загального стану пацієнтів і як наслідок - якості життя під час лікування. Пацієнти групи 1 відмітили покращення свого самопочуття вже на 2-й день після проведення аутодермопластики. При цьому спостерігали зменшення вираження ознак больового синдрому, загальної інтоксикації.

2. Запропонований метод пластики опікових ран 3 використанням аутодермотрансплантатів ультратонкого зрізу є високоефективною методикою відновлення дермальних дефектів і може бути рекомендований як ресурсозберігаючий метод хірургічного лікування ран у хворих з опіками, особливо при великій площі термічного ураження в постраждалих із вираженим дефіцитом донорських ресурсів шкіри. 


\section{З ДОСВІДУ РОБОТИ}

\section{СПИСОК ЛІТЕРАТУРИ}

1. Подурець Д. П. Хірургічне лікування великих субфасціальних опіків з оголенням кісток гомілки : автореф. дис. на здобуття наук. ступеня канд. мед. наук : спец. 14.01.03. “Хірургія” / Дмитро Петрович Подурець ; Ін-т невідкладної і відновної хірургії ім. В. К. Гусака АМН України. - Донецьк, 2008. - 20 с.

2. Козинець Г. П. Опікова хвороба / Г. П. Козинець, О. Н. Коваленко, С. В. Слесаренко // Мистецтво лікування. - 2006. № 12. - С. 9-15.

3. Шаповал О. В. Інфузійне лікування в період опікового шоку як фактор зменшення ризику летальності / О. В. Шаповал // Актуальные проблемы медицины и биологии. - 2003. - № 1. 4. Грязін О. Є. Оптимізація раннього хірургічного лікування опікових ран шляхом подолання дефіциту донорських ресурсів шкірного покриву у важко обпечених : автореф. дис. на здобуття наук. ступеня канд. мед. наук : спец. 14.01.03. 5. Трофимов Е. И. Результаты лечения пациентов с мягкотканными дефектами кисти и области лучезапястного сустава свободными микрохирургическими аутотрансплантатами / Е. И. Трофимов, Т. Ю. Гурджидзе, Г. Р. Мехтиханова // IV Международный конгресс по пластической, реконструктивной и эстетической хирургии, 8-10 октября 2010 г. : материалы конгр. - Тбилиси, 2010. - С. 24.

6. Жернов О. А. Реконструктивно-відновне лікування наслідків термічної травми 3 використанням модифіковах комплексів тканин / О. А. Жернов // Шпитальна хірургія. -
2007. - № 2. - C. 88-91.

7.http://ujcem.med.sumdu.edu.ua/images/sampledata/2013/4/390 _397_IV-016.pdf

8. http://uareferat.com/\%D0\%9C\%D0\%B5\%D1\%82\%D0\%BE\% D0\%B4\%D0\%B8_\%D0\%BE\%D1\%86\%D1\%96\%D0\%BD\%D 0\%BA\%D0\%B8_\%D0\%BA\%D1\%80\%D0\%BE\%D0\%B2\%D0 \%BE\%D0\%B2\%D1\%82\%D1\%80\%D0\%B0\%D1\%82\%D0\%B8 _\%D0\%B2_\%D0\%B0\%D0\%BA\%D1\%83\%D1\%88\%D0\%B5\% D1\%80\%D1\%81\%D1\%82\%D0\%B2\%D1\%96

9. http://i-medic.com.ua/index.php?newsid=11211 10. http://elkniga.info/book_39_glava_9_PRAKTICHN\%D0\%86_ ROBOTI.html

11. Посібник з нормальної фізіології / за ред. В. Г. Шевчука, Д. Г. Наливайка. - К., 1995. - С. 105-108, 113-126.

12. Філімонов В. І. Фізіологія людини : підручник / В. І. Філімонов. - К. : ВСВ “Медицина”, 2010. - С. 424-443.

13. http://gn24.net/publ/surgery/raschjot-krovopoteri-po-gematok ritnom.html

14. Михайленко С. М. Оптимізація трансфузійної допомоги у хворих $з$ політравмою : робота на здобуття наукового ступеня магістра ; спец. 14.01.21 - травматологія та ортопедія / С. М. Михайленко ; наук. кер. В. Д. Шищук. - Суми : СумДУ; Мед. ін-т, 2012. -47 c.

15.http://physiology.med.sumdu.edu.ua/index.php?option=com content\&view=article\&id=75\&Itemid=37\&lang=ru

Отримано 18.03.15 